\title{
PRODUCTION OF FUNCTIONAL SPREADABLE PROCESSED CHEESE USING CHLORELLA VULGARIS
}

\author{
Mounir Mohamad Tohamy ${ }^{1}$, Mansour Abdo Ali ${ }^{1}$, Hamdy Abdel-Gawwad Shaaban², \\ Ashraf Gaber Mohamad ${ }^{3}$, Ahmad Mohamad Hasanain ${ }^{1 \bowtie}$ \\ ${ }^{1}$ Faculty of Agriculture, Dairy Science Department, Al-Azhar University, Nasr city, Cairo, Egypt \\ ${ }^{2}$ Chemistry of Flavour and Aroma Department, National Research Center, Dokki, Cairo, Egypt \\ ${ }^{3}$ Dairy Science Department, National Research Center, Dokki, Cairo, Egypt
}

\begin{abstract}
Background. Chlorella vulgaris alga is one of the most important additives for enhancing the nutritional content of conventional foods, hence positively affecting human health. This alga is known as a rich source of protein, fatty acids, fiber, essential vitamins and minerals. Also, it contains antioxidants, omega 3, antivi$\mathrm{ral}$ and anticancer properties. The aim of this research is increasing the nutritional and potential therapeutic value of processed cheese by using Chlorella vulgaris alga, taking advantage of its high nutritional and health value.

Materials and methods. The ingredients in the processed cheese blends were mature cheddar cheese, Ras cheese, butter, skimmed milk powder, Emulsifying salts (K-2394, S9s \& S4), Chlorella vulgaris (in freezedried and slurry forms). Chemical, rheological and sensory evaluation properties were evaluated in processed cheese analogue (PCA) treatments when fresh and after three months of cold storage at $5-7^{\circ} \mathrm{C}$. PCA treatments were enriched with $2 \%, 4 \%$ and $6 \%$ dried Chlorella vulgaris powder in the cheese blends and $4 \%$ Chlorella vulgaris slurry.

Results. The incorporation of alga into processed cheese led to an increase in their functional characteristics. The results of sensory evaluation of PCA samples demonstrated that $2 \%$ of alga addition was the best treatment, followed by $4 \%$, but that the level of $6 \%$ was unacceptable to consumers. The studied alga enhanced the cheese analog with the high levels of selenium, zinc, iron, magnesium and potassium. Antioxidant activity in the cheese enhanced with Chlorella vulgaris was higher than the control sample. To improve some properties of PCA, other emulsifying salts (S9S and S4) were tested and the alga was added in the form of slurry with value of $4 \%$ into the cheese blend. Both S9S and S4 emulsifying salts were good and the S4 was the best for oiling off and meltability. Also, when using the slurry of Chlorella vulgaris, the granular texture of the cheese analog completely disappeared.

Conclusions. The results showed that the alga indeed increased nutrition values and health benefits to the processed cheese, making it a substantial functional food. Therefore, we recommend supporting the manufacture of the processed cheese analogue with the addition of $2 \%$ Chlorella vulgaris alga in soft powder form and $4 \%$ Chlorella vulgaris alga in slurry form at the end of the processing.
\end{abstract}

Keywords: processed cheese, algae, Chlorella vulgaris, antioxidant activity

\footnotetext{
『Ahmadsheme1@gmail.com
} 


\section{INTRODUCTION}

Processed cheese is a very important dairy product, which is produced and handled easily without the need for special conditions due to its high conservation capacity. It is also a very popular product, especially for children owing, to pleasant flavor and distinctive texture. Processed cheese differs from natural cheese in the fact that processed cheese is not made directly from milk. However, the main ingredient of processed cheese is natural cheese. Processed cheese is produced by blending natural cheeses of different ages and degrees of maturity in the presence of emulsifying salts and other dairy and nondairy ingredients, followed by heating and continuous mixing to form a homogeneous product with an extended shelf life (Guinee et al., 2004; Meyer, 1973; Thomas, 1973). The initial idea of processed cheese was to increase the shelf life of natural cheese and find alternative uses for natural cheese that was difficult to sell. In recent times, there was an interest in the development of processed cheese in order to raise its nutritional value to benefit people who suffer from diseases such as heart disease or hardening of the arteries, reduce the cost of production or increase the shelf life. In the United States, the development of processed cheese was brought about by Kraft in 1916, when he preserved natural cheese in cans by heating and mixing it in order to increase its shelf life (Kapoor and Metzger, 2008). Also, new varieties of processed cheese were invented using non-conventional additives, such as the production of processed cheese with peppers, spices, oat and olives and smoked processed cheese etc. The nutritional and potential therapeutic value of food is a key characteristic in the development of new value-added products that are manufactured for health-conscious consumers (Fox et al., 2017).

The aim of this research is increasing the nutritional and potential therapeutic value of processed cheese analogue using Chlorella vulgaris alga, due to its high nutritional and health value. It was cultivated as a source of highly valuable molecules such as polyunsaturated fatty acids, pigments, antioxidants, pharmaceuticals and other biologically active compounds (Gouveia et al., 2008). Chlorella sp. has been used for many centuries as a nutrient-dense food in Asia, Africa and Mexico. However commercial large-scale production of microalgae only began in the early 1960s (Japan), and nowadays microalgae are mainly marketed as food supplements, commonly sold in the form of tablets, capsules or liquids. Additionally, there is an increasingly growing market for food products with added microalgae, such as pastas, biscuits, bread, snack foods, candy bars or gums, yogurts, drink mixes, soft drinks, etc., either as nutritious supplement, or as a source of natural food colorant (Becker, 2007).

Chlorella sp. contains high-antioxidant components, abundant amino acids, high-quality proteins, $\mathrm{Fe}$ and $\mathrm{Ca}$, unsaturated fatty acids, and many types of vitamins including $\mathrm{A}, \mathrm{B} 2, \mathrm{~B} 6, \mathrm{~B} 8, \mathrm{~B} 12$, E and $\mathrm{K}$. It has antiviral and anti-tumor effects and reduces blood lipids, blood sugar, body weight, and wound healing time. Therefore, it is known as therapeutic and functional food (Gyenis et al., 2005; Kreitlow et al., 1999; Merchant and Andre, 2001). Chlorella sp. has health benefits, such as ameliorating disorders such as gastric ulcers, wounds, constipation, anemia and hypertension and has immune-modulating and anticancer properties, and is also a promising ingredient in the food industry (Mohamed et al., 2013)

The present study was undertaken to gain more knowledge about using Chlorella vulgaris as an alimentary and healthy supplement in a processed cheese analogue.

\section{MATERIALS AND METHODS}

\section{Materials}

Mature cheddar cheese (6 months old) was imported from New Zealand by Khaled Khoshala Co. for Food Industries \& Cooling, Egypt. Ras cheese (1 month old) was obtained from Mariam Co., Giza, Egypt. Fonterra butter was obtained from Sakr Group Co., Egypt. Low-heat skimmed milk powder was from the Irish Dairy Board, Grattan House, Lower Mount St., Dublin, Ireland. Kasomel emulsifying salt (K-2394) was obtained from Rhone-Poulenc Chimie, France. Joha S9S emulsifying salt was obtained from the BK Giulini Chemie GmbH, Landenberg, Germany. Joha S4 emulsifying salt was obtained from Rhone-Poulenc Chimie, France. Chlorella vulgaris biomass, in freeze-dried and slurry forms, were obtained from the Algal Biotechnology Unit, National Research Centre, 
Tohamy, M. M., Ali, M. A., Shaaban, H. A.-G., Mohamad, A. G., Hasanain, A. M. (2018). Production of functional spreadable processed cheese using Chlorella vulgaris. Acta Sci. Pol. Technol. Aliment., 17(4), 347-358. http://dx.doi.org/10.17306/J.AFS.2018.0589

Table 1. Composition of raw materials used in the manufacture of the processed cheese analogue

\begin{tabular}{lcccccc}
\hline $\begin{array}{c}\text { Character } \\
\text { assessed }\end{array}$ & Cheddar cheese & Ras cheese & Butter & $\begin{array}{c}\text { Skimmed milk } \\
\text { powder }\end{array}$ & $\begin{array}{c}\text { Dried Chlorella } \\
\text { vulgaris }\end{array}$ & $\begin{array}{c}\text { Slurry Chlorella } \\
\text { vulgaris }\end{array}$ \\
\hline Total solids & 65.8 & 54.81 & 84 & 96 & 94.17 & 10.9 \\
Fat & 34.8 & 24.77 & 81.99 & 0.97 & 12.18 & 1.41 \\
Crude protein & $25.47^{*}$ & $22.26^{*}$ & $\mathrm{ND}$ & $37.13^{*}$ & $51.45^{* *}$ & $5.96^{* *}$ \\
Ash & 5.42 & 5.76 & $\mathrm{ND}$ & 7.89 & 9.5 & 1.1 \\
Carbohydrate & 0.1 & 1.64 & $\mathrm{ND}$ & 47.43 & 11.86 & 1.37 \\
Fiber & $\mathrm{ND}$ & $\mathrm{ND}$ & $\mathrm{ND}$ & $\mathrm{ND}$ & 9.18 & 1.06 \\
\hline
\end{tabular}

$\mathrm{ND}-$ non detected. $*$ Protein $\%-\mathrm{N} \times 6.38$. **Protein $\%-\mathrm{N} \times 4.38$.

Dokki, Cairo, Egypt. Table 1 shows the chemical composition of the ingredients used in the manufacture of processed cheese analogue.

\section{Methods}

Preparation of alga. The alga was used as powder in the blend. Clean growth was performed in a 1200 L Zigzag photo-bioreactor, according to El-Sayed (2011), in the presence of the growth media as described by El-Sayed et al. (2001). For harvesting and cleaning of the obtained biomass, a series of precipitation and washing processes were performed using tap water and a cooling centrifuge (HEIDELBERG RUNNE, RSU-20).

Manufacture of the processed cheese analogue (PCA). Processed cheese analogue (PCA) was manufactured as described by Savello et al. (1989) with some modifications. All experimental PCA treatments were formulated to yield PCA with $50-55 \%$ moisture and $48-50 \%$ fat-in-dry-matter. The PCA treatments were manufactured using dried Chlorella vulgaris in ratios of $2 \%, 4 \%$ and $6 \%$ and slurry of Chlorella vulgaris in a ratio of $4 \%$ as shown in Table 2 . The processed cheese and PCA treatments were prepared by blending the dry ingredients with previously warmed $\left(50^{\circ} \mathrm{C}\right)$ milk fat into a processing batch type kettle of $10 \mathrm{~kg}$ capacity, at the pilot plant unit of the National Research Centre. Cooking was carried out using direct an injection of steam at a pressure of 1.5 bar to $66^{\circ} \mathrm{C}$ with continuous agitation for $4 \mathrm{~min}$. The blends were further heated to a final temperature of $82^{\circ} \mathrm{C}$ in approximately $4 \mathrm{~min}$. The blends were held at $82^{\circ} \mathrm{C}$ for $1 \mathrm{~min}$ to add the alga, prior to pouring into tin cans, then stored at $5-7^{\circ} \mathrm{C}$.

Methods of analysis. The nutrient profile of Chlorella vulgaris was determined by AOAC (2006) in terms of moisture, ash, protein, fat and fiber contents. Total carbohydrate contents were calculated by difference. For the cheese samples, total solids content, fat content, titratable acidity, soluble nitrogen and total protein content were determined as described by Ling (1963). The ash content was determined according to the method by AOAC (2006). Salt content was determined as described by Bradley et al. (1992). The $\mathrm{pH}$ values were measured using a laboratory digital pH meter model Adwa 1030. Mineral contents were measured using flame ionization by Atomic Absorption Spectrophotometer (model: GBC932AA) at the Regional Centre for Food and Feed, Agricultural Research Center, Giza. The fiber content was determined according to AOAC (2006). Vitamins were analyzed at the National Research Center as mention by De Leenheer and Lambert (2000). Antioxidant activity was determined at the National Research Center according to Hatano et al. (1988) with some modifications. Oiling off was determined according to the method outlined by Thomas (1973). Meltability of the sample of processed cheese was determined according to the method designed by Olson and Price (1958) and slightly modified by Savello et al. (1989). Texture properties of PCAs were analyzed using a universal testing machine (Instron), as described by Bourne 
Tohamy, M. M., Ali, M. A., Shaaban, H. A.-G., Mohamad, A. G., Hasanain, A. M. (2018). Production of functional spreadable processed cheese using Chlorella vulgaris. Acta Sci. Pol. Technol. Aliment., 17(4), 347-358. http://dx.doi.org/10.17306/J.AFS.2018.0589

Table 2. Formulations of different processed cheese analogue with dried Chlorella vulgaris, $\mathrm{kg} / 100 \mathrm{~kg}$

\begin{tabular}{lccccccc}
\hline & \multicolumn{6}{c}{ Control } & \multicolumn{5}{c}{ Chlorella processed cheese } \\
\cline { 2 - 8 } \multicolumn{1}{c}{ Ingredients } & (K-2394) & S9s or S4 & $\begin{array}{c}\text { dried alga } \\
2 \%^{*}\end{array}$ & $\begin{array}{c}\text { dried alga } \\
4 \% *\end{array}$ & $\begin{array}{c}\text { dried alga } \\
6 \%^{*}\end{array}$ & $\begin{array}{c}\text { dried alga } \\
(4 \%)^{* *}\end{array}$ & $\begin{array}{c}\text { slurry alga } \\
(4 \%)^{* * *}\end{array}$ \\
\hline Cheddar cheese & 12.8 & 12.8 & 12.8 & 12.8 & 12.8 & 12.8 & 16 \\
Ras cheese & 38.44 & 38.44 & 36.09 & 35.53 & 34.92 & 35.53 & 38 \\
Skimmed milk powder & 5.12 & 5.92 & 4 & 2 & 1 & 2.8 & 2 \\
Butter & 10.26 & 10.26 & 10 & 10.26 & 11 & 10.26 & 10 \\
Salt & - & - & 0.1 & 0.2 & 0.3 & 0.2 & 0.2 \\
Emulsifying salt & 2.5 & 1.7 & 2.5 & 2.5 & 2.5 & 1.7 & 1.7 \\
Chlorella vulgaris & - & - & 2 & 4 & 6 & 4 & 4 \\
Water & 30.88 & 30.88 & 32.51 & 32.71 & 31.48 & 32.71 & 28.1 \\
\hline
\end{tabular}

K-2394 - Kasomel emulsifying salts (K-2394).

*Treatments made using different emulsifying salts (K-2394).

**Treatments made using different emulsifying salts (S9S and S4).

***Treatment made using only S4 emulsifying salt.

(2002) and Szczesniak et al. (1963). Statistical analyses were performed using Statistical Package for the Social Sciences (SPSS version 20 (IBM)) software. Each preparation and measurement was conducted in triplicate. The experimental data were subjected to an analysis of variance for a completely random design. Duncan's multiple range tests were used to determine the difference among means at the level of 0.05 .

Organoleptic properties evaluation. All samples of processed cheese were evaluated organoleptically for different sensory properties using a hedonic scale of $1-5$, which was designed based on the hedonic scales provided by Brandt et al. (1963), Caul (1957) and Larmond (1977). The sensory evaluation was carried out by 15 staff members of the Dairy Department, Al-Azhar University.

\section{RESULTS AND DISCUSSION}

\section{Effect of adding dried Chlorella vulgaris on properties of processed cheese}

This part discusses the manufacture of a functional dairy product by mixing processed cheese with $2 \%$, $4 \%$ and $6 \%$ of dried Chlorella vulgaris using Kasomel emulsifying salts (K-2394). The effect of the addition of the alga on the sensory, chemical and rheological properties of the processed cheese was then investigated to see whether alga addition could have an added value on the nutrition benefits of the processed cheese since they carry a high value of nutrition and health benefits in themselves. The research has revealed the following results.

Sensory evaluation for processed cheese with/ without alga. Table 3 presents the results of adding $2 \%, 4 \%$ and $6 \%$ Chlorella vulgaris alga to sensory properties of the processed cheese analogue. The products with $2 \%$ and $4 \%$ added Chlorella vulgaris alga did not exhibit and significant difference in terms of the breakdown properties, stickiness and chewiness. Also, a granular texture appeared in the cheese analog and increased when the percentage of added alga was raised. The best treatment of cheese analog was the cheese with $2 \%$ added Chlorella vulgaris, which was the nearest to the control sample. Overall preference score for the $2 \%$ chlorella cheese sample was 4 from 5 , compared to the control sample which was 4.5 from 5 , whereas the $4 \%$ chlorella cheese sample was 3 from 5 . The processed cheese with $6 \%$ Chlorella vulgaris alga showed marked differences in most properties of the sensory assessment, and hence this sample was rejected. On the 
Tohamy, M. M., Ali, M. A., Shaaban, H. A.-G., Mohamad, A. G., Hasanain, A. M. (2018). Production of functional spreadable processed cheese using Chlorella vulgaris. Acta Sci. Pol. Technol. Aliment., 17(4), 347-358. http://dx.doi.org/10.17306/J.AFS.2018.0589

Table 3. Sensory evaluation of processed cheese with dried Chlorella vulgaris

\begin{tabular}{|c|c|c|c|c|c|c|}
\hline \multirow[t]{2}{*}{ Attribute } & \multirow[t]{2}{*}{ Control } & \multicolumn{3}{|c|}{$\begin{array}{l}\text { Processed cheese made } \\
\text { using Chlorella vulgaris }\end{array}$} & \multicolumn{2}{|c|}{ Score limit (1-5) } \\
\hline & & $2 \%$ & $4 \%$ & $6 \%$ & & \\
\hline Surface appearance & 3 & 3.5 & 3.7 & 3.8 & (1) very dull & (5) very shiny \\
\hline Firmness of body & 2 & 2 & 2.5 & 3 & (1) very soft & (5) very firm \\
\hline Spreading quality & 3 & 3 & 4 & 5 & (1) difficult to spread & (5) easy to spread \\
\hline Stickiness & 3 & 2 & 2 & 1 & (1) not sticky & (5) very sticky \\
\hline Smoothness of texture & 4.5 & 3 & 2 & 2 & (1) not smooth & (5) very smooth \\
\hline Breakdown properties & 4 & 3.3 & 3 & 2 & (1) does not dissolve & (5) dissolves very well \\
\hline Chewiness & 4.5 & 3 & 2.5 & 1 & (1) not chewy & (5) very chewy \\
\hline Gumminess & 2 & 2 & 1.5 & 1 & (1) absent & (5) very pronounced \\
\hline Oiling off & 1 & 1.5 & 3 & 3.5 & (1) absent & (5) very pronounced \\
\hline Flavor & 3 & 3 & 4 & 5 & (1) very weak & (5) very strong \\
\hline Saltiness & 3 & 3 & 3.5 & 3.5 & (1) not salty & (5) very salty \\
\hline Over all preference & 4.5 & 4 & 3 & 2 & (1) dislike very much & (5) like very much \\
\hline
\end{tabular}

basis of the above results, further investigation was only carried out for the products with $2 \%$ and $4 \%$ addition of dried Chlorella vulgaris alga.

Chemical analysis of the studied processed cheese. The results of the chemical analysis presented in Table 4 indicate that the addition of the alga to the processed cheese increased the fat content slightly, from $19.5 \%$ for the control sample to $19.8 \%$ and $20.5 \%$ for the processed cheese with $2 \%$ and $4 \%$ Chlorella vulgaris alga respectively. The processed cheese with $4 \%$ Chlorella vulgaris also exhibited the highest level of total protein (TP) $(12.25 \%)$ compared to the control sample which, only contained $12 \%$ TP. This is due to the fact that the Chlorella vulgaris alga biomass has high protein content; around 55.7\% (Radhakrishnan et al., 2017). The alga added fiber - about $0.11 \%$ and $0.16 \%$ for processed cheese supplemented with $2 \%$ and $4 \%$ of $C$. vulgaris respectively, which can be attributed to the fiber content in the alga biomass mentioned by Abdel-Razik and Mohamed (2013).

It was also found that the addition of alga to the processed cheese increased the ash content of the processed cheese. The highest level of ash was in cheese with 4\% Chlorella vulgaris (3.05\%), while the lowest level was in the control sample (2.26\%), and this result is in agreement to what was mentioned by Shalaby and Yasin (2013), which also indicates that the addition of alga is responsible for adding mineral elements to the product.

Table 4. Chemical composition of the processed cheese analogue, $\%$

\begin{tabular}{lccc}
\hline \multirow{2}{*}{ Analysis } & Control & \multicolumn{2}{c}{ Chlorella vulgaris cheese } \\
\cline { 3 - 4 } & & $2 \%$ & $4 \%$ \\
\hline Fat & $19.5^{\mathrm{b}}$ & $19.8^{\mathrm{b}}$ & $20.5^{\mathrm{a}}$ \\
Total solids & $39.73^{\mathrm{c}}$ & $40.87^{\mathrm{b}}$ & $43.24^{\mathrm{a}}$ \\
Fat/dry matter & $47.82^{\mathrm{b}}$ & $48.45^{\mathrm{a}}$ & $47.41^{\mathrm{c}}$ \\
Salt & $1.19^{\mathrm{a}}$ & $1.11^{\mathrm{b}}$ & $1.11^{\mathrm{b}}$ \\
Total protein & $12^{\mathrm{b}}$ & $12.13^{\mathrm{ab}}$ & $12.25^{\mathrm{a}}$ \\
Ash & $2.26^{\mathrm{c}}$ & $2.93^{\mathrm{b}}$ & $3.05^{\mathrm{a}}$ \\
Fiber & 0 & $0.11^{\mathrm{b}}$ & $0.16^{\mathrm{a}}$ \\
\hline
\end{tabular}

Means with same letters in a row are not significant $(P \leq 0.05)$. 
Tohamy, M. M., Ali, M. A., Shaaban, H. A.-G., Mohamad, A. G., Hasanain, A. M. (2018). Production of functional spreadable processed cheese using Chlorella vulgaris. Acta Sci. Pol. Technol. Aliment., 17(4), 347-358. http://dx.doi.org/10.17306/J.AFS.2018.0589

Table 5. Changes in $\mathrm{pH}$ and titratable acidity during storage for processed cheese made using dried Chlorella vulgaris

\begin{tabular}{lccc}
\hline \multirow{2}{*}{$\begin{array}{l}\text { Storage } \\
\text { periods }\end{array}$} & Control & \multicolumn{2}{c}{ Chlorella vulgaris cheese } \\
\cline { 3 - 4 } $\mathrm{pH}$ & & $2 \%$ & $4 \%$ \\
Fresh & $5.77^{\mathrm{Aa}}$ & $5.92^{\mathrm{Aa}}$ & $6^{\mathrm{Aa}}$ \\
1-month & $5.72^{\mathrm{Bc}}$ & $5.86^{\mathrm{Bb}}$ & $5.99^{\mathrm{Aa}}$ \\
2-months & $5.7^{\mathrm{Bc}}$ & $5.75^{\mathrm{Cb}}$ & $5.96^{\mathrm{Aa}}$ \\
3-months & $5.67^{\mathrm{Cb}}$ & $5.65^{\mathrm{Dc}}$ & $5.93^{\mathrm{Aa}}$ \\
Titratable acidity & & \\
Fresh & $1.4^{\mathrm{Ba}}$ & $1.3^{\mathrm{Ba}}$ & $1.2^{\mathrm{Ba}}$ \\
1-month & $1.5^{\mathrm{Ba}}$ & $1.4^{\mathrm{Ba}}$ & $1.3^{\mathrm{Ba}}$ \\
2-months & $1.7^{\mathrm{Aa}}$ & $1.6^{\mathrm{Aa}}$ & $1.5^{\mathrm{Aa}}$ \\
3-months & $1.8^{\mathrm{Aa}}$ & $1.7^{\mathrm{Aa}}$ & $1.6^{\mathrm{Aa}}$ \\
\hline
\end{tabular}

Means followed by the same capital letters $(\mathrm{A}-\mathrm{C})$ in the same row and values followed by the same small letters $(\mathrm{a}-\mathrm{c})$ in the same columns are not significantly different $(P \leq 0.05)$.

The pH level and acidity of studied cheese. The results in Table 5 indicate that the $\mathrm{pH}$ level increased with the percentage of alga added. This may be due to the $\mathrm{pH}$ value of the algae themselves; Abdel-Razik and Mohamed (2013) mentioned that the $\mathrm{pH}$ value is 6.5 for Chlorella vulgaris biomass. When storing all products at $7^{\circ} \mathrm{C}$, the $\mathrm{pH}$ value was noticed to decrease as the storage duration increased, which could be attributed to the acidity increase of the cheese during storage, which can be observed in Table 5 and conforms to the report of Faten et al. (2014) and Nayra et al. (2017).

Mineral content of the processed cheese with/ without alga. The results presented in Table 6 indicate that the alga added a number of minerals that are important in the human body. Selenium, which has antioxidant and anti-cancer properties as reported by Rayman (2000), was found at $25.11 \mathrm{mg} / \mathrm{kg}$ content in the processed cheese with $4 \%$ Chlorella vulgaris, compared to $2.494 \mathrm{mg} / \mathrm{kg}$ in the control sample.

The addition of the alga increased the zinc content to $36.98 \mathrm{mg} / \mathrm{kg}$ for the processed cheese with $4 \%$ Chlorella vulgaris addition. Bimola et al. (2014)
Table 6. Mineral content of processed cheese made using Chlorella vulgaris, $\mathrm{mg} / \mathrm{kg}$

\begin{tabular}{lcc}
\hline Nutrients & Control & $\begin{array}{c}\text { Cheese with 4\% addition } \\
\text { of Chlorella vulgaris }\end{array}$ \\
\hline Selenium & 2.494 & 25.11 \\
Zinc & 0.41 & 36.98 \\
Iron & 6.938 & 52.26 \\
Magnesium & 17.27 & 38.53 \\
Calcium & 395.4 & 436.2 \\
Potassium & 46.39 & 62.69 \\
\hline
\end{tabular}

reported that zinc is important for the human body to care for the skin, teeth, bones, hair, nails, muscles, nerves and brain function. The body uses zinc to heal wounds and pneumonia, in addition to its support for body growth. Chlorella vulgaris added iron content to the processed cheese, recorded at $52.26 \mathrm{mg} / \mathrm{kg}$ for the $4 \%$ Chlorella vulgaris sample compared to only $6.938 \mathrm{mg} / \mathrm{kg}$ for the control sample. Iron is one of the most important nutrients for the body, as it is one of the elements forming hemoglobin in red blood cells, as well as one of the elements forming myoglobin that distributes oxygen throughout the body and stores oxygen in the muscles and tissues. Also, iron is an element in the formation of many enzymes that the body needs for its generation of energy, as mentioned by Jackson (2010). The Chlorella vulgaris cheese sample showed a high content of magnesium; $38.53 \mathrm{mg} / \mathrm{kg}$ compared to $17.27 \mathrm{mg} / \mathrm{kg}$ for the control sample. Magnesium is another important element that the body uses to regulate the transfer of nerve signals and nerve connectivity. Magnesium also regulates muscle contraction, blood pressure and insulin metabolism. It also plays an important role in the treatment of many diseases, such as Alzheimer's, insulin resistance, diabetes, high blood pressure and heart and blood vessel disorders such as strokes and migraines, as reported by Gröber et al. (2015). The samples with alga did not show significant increase in the calcium content compared to the control sample, as calcium is already one of the main nutrients in milk.

The results also indicated high potassium content, which was reported at $62.69 \mathrm{mg} / \mathrm{kg}$ for the Chlorella 
vulgaris cheese, compared to $46.39 \mathrm{mg} / \mathrm{kg}$ for the control sample. Lanham-New and Lambert (2012) reported that high doses of potassium have a positive effect against many problems that affect the cardiac system, kidneys, bones and blood vessels. Continuous intake of potassium reduces blood pressure and is also effective in reducing the risks of strokes and preventing chronic kidney damage. There has been a growing volume of reports indicating the strong relationship between potassium intake and positive effects on the function of muscles. Alga contain all these minerals and more as reported by Radhakrishnan et al. (2017) and Tokuşoglu and Üunal (2003) and this explains their higher content in the Chlorella vulgaris cheese.

Vitamin content of the studied processed cheese. Some species of algae are considered an important source of essential vitamins such as: A, B1, B2, B6, B8, B12, E, K, C, biotin (B7), pantothenate (B5), nicotinic acid (B3) and folic acid (Beheshtipour et al., 2013). Vitamins are vitally important compounds that the human body needs in order to carry out many functions, such as producing body tissues and protecting against many diseases.

Table 7 presents the content of some of the vitamins that were investigated in this study in the studied processed cheese and concluded that the alga slightly increased the vitamin content of the cheese produced with the alga, especially vitamin A, B2, B6, $\mathrm{D}$ and $\mathrm{E}$.

The vitamin A content was found to be $5.853 \mu \mathrm{g} / \mathrm{g}$ for Chlorella vulgaris cheese compared to $5.093 \mu \mathrm{g} / \mathrm{g}$ for the control sample. The content of vitamin D in the

Table 7. Vitamin content of the processed cheese made using algae, $\mu \mathrm{g} / \mathrm{g}$

\begin{tabular}{ccc}
\hline & \multicolumn{2}{c}{ Treatments } \\
\cline { 2 - 3 } Vitamins & control & $\begin{array}{c}\text { cheese with 4\% addition } \\
\text { of Chlorella vulgaris }\end{array}$ \\
\hline A & 5.093 & 5.853 \\
D & 0.545 & 0.582 \\
E & 7.013 & 7.135 \\
B2 & 4.917 & 5.01 \\
B6 & 0.752 & 2.103 \\
\hline
\end{tabular}

Chlorella vulgaris cheese was $0.582 \mu \mathrm{g} / \mathrm{g}$ compared to $0.545 \mu \mathrm{g} / \mathrm{g}$ for the control sample. The vitamin B6 content in the Chlorella vulgaris cheese was found to be $2.103 \mu \mathrm{g} / \mathrm{g}$ compared to $0.752 \mu \mathrm{g} / \mathrm{g}$ for the control sample. The vitamin B2 content in the Chlorella vulgaris cheese was found to be $5.010 \mu \mathrm{g} / \mathrm{g}$ compared to $4.917 \mu \mathrm{g} / \mathrm{g}$ for the control sample. These vitamin contents are basically an indication of the presence of these vitamins in the algal biomass as reported by Blas-Valdivia et al. (2011) and Gyenis et al. (2005).

Meltability of the studied processed cheese. Table 8 presents the relationship between the meltability of the processed cheese and the effect of adding alga to the processed cheese, at zero time and during storage at $5-7^{\circ} \mathrm{C}$. The addition of alga to the processed cheese increased the degree of meltability compared with the control sample both, for at zero time and after storage. The $4 \%$ Chlorella vulgaris cheese had the highest degree of meltability $(186 \mathrm{~mm})$ while the control sample had the lowest $(57 \mathrm{~mm})$. The meltability of the cheese increased with increasing storage time for all treatments. Mohamed et al. (2013) reported that the

Table 8. Changes in the melting index and oiling off during storage of processed cheese made using microalgae

\begin{tabular}{lccc}
\hline \multirow{2}{*}{$\begin{array}{l}\text { Time under } \\
\text { cold storage }\end{array}$} & Control & \multicolumn{2}{c}{ Chlorella vulgaris cheese } \\
\cline { 3 - 4 } & & $2 \%$ & $4 \%$ \\
\hline Melting index, mm & & & \\
Fresh & $57^{\mathrm{Ac}}$ & $141^{\mathrm{Ab}}$ & $175^{\mathrm{Aa}}$ \\
1-month & $57^{\mathrm{Ac}}$ & $145^{\mathrm{Ab}}$ & $180^{\mathrm{Aa}}$ \\
2-months & $58^{\mathrm{Ac}}$ & $147^{\mathrm{Ab}}$ & $183^{\mathrm{Aa}}$ \\
3-months & $60^{\mathrm{Ac}}$ & $150^{\mathrm{Ab}}$ & $186^{\mathrm{Aa}}$ \\
Oiling off, \% & & & \\
Fresh & $40^{\mathrm{Db}}$ & $41^{\mathrm{Db}}$ & $43^{\mathrm{Da}}$ \\
1-month & $44^{\mathrm{Cc}}$ & $46^{\mathrm{Cb}}$ & $52^{\mathrm{Ca}}$ \\
2-months & $50^{\mathrm{Bb}}$ & $59^{\mathrm{Ba}}$ & $60^{\mathrm{Ba}}$ \\
3-months & $54^{\mathrm{Ac}}$ & $84^{\mathrm{Ab}}$ & $96^{\mathrm{Aa}}$ \\
\hline
\end{tabular}

Means followed by the same capital letters $(\mathrm{A}-\mathrm{D})$ in the same row, and values followed by the same small letters $(\mathrm{a}-\mathrm{c})$ in the same columns are not significantly different $(P \leq 0.05)$. 
degree of meltability of the processed cheese could be affected by the ingredients of the products, and/or the increased rigidity and reduced flowing rate could be attributed to the reduction of the size of the fat granules. Solowiej (2007) found that the viability of fusion is related to the increase in $\mathrm{pH}$ value, the smoothness in texture, the high degree of disintegration of casein and the reduction of fat emulsification. The soft texture of the processed cheese, together with an increase in the moisture content, could also lead to an increase of the meltability.

Oiling off. The degree of oiling off in the studied processed cheese is recorded in Table 8. While the control sample indicated a value of 40 for the degree of oiling off, Chlorella vulgaris cheese with $2 \%$ and $4 \%$ alga content recorded 41 and 43 for the degree of oiling off at the zero time respectively.

Suhila et al. (2016) mentioned that the low degree of oiling off could be attributed to the high stability of the emulsified material and the good fat emulsification in the texture. During storage of the processed cheese, all products showed a gradual increase in the degree of oiling off proportional to the storage duration. The control sample recorded the lowest value; these results were in agreement with Shamsia et al. (2011).

Bachmann (2001) and Hassan et al. (2007) pointed out that the increase in oiling off could be due to the existence of another protein other than casein in the processed cheese mixture, which makes the cheese less capable of keeping the protein inside with the fat in the emulsion, and this is more likely to take place as the storage period is increased. On the other hand, the milk protein and its content of casein, which possesses the ability to form texture (structure of cheese and strength) and react with the balance system, results in an increase in the ability to hold fat in the emulsified material and in the reduction of oiling off during the storage period.

This also explains the increase in oiling off in the cheese products with alga, as they contain small portions of algal protein and hence were less capable of keeping the fat inside, as in the case of the casein in milk. This will therefore result in a relative increase in the oiling off in the cheese products with alga compared to the control sample. Therefore, it is possible to control oiling off by selecting suitable emulsifying salts for the manufacture of processed cheese.

Antioxidant activity. Among the unique characteristics of algae is its content of strong antioxidants that renders algae an important health supporter, as these anti-oxidants prevent the damage of tissues due to free radicals by either preventing free radicals from forming or by catalyzing their disintegration, and hence preventing cancer (Surh, 2003). Matsukawa et al. (1998) reported that 100 algae have been extracted from hot water springs and ponds in Japan that have high antioxidant properties. This allowed their use in the manufacture of many materials, medicines and cosmetics (Tramper et al., 2003). Blas-Valdivia et al. (2011) indicated that Chlorella vulgaris contains many antioxidants, such as lutein and chlorophyll, and metal antioxidants such as selenium. In this study, the activity of the antioxidants in the cheese with alga were investigated and compared with those of the control sample as shown in Table 9. It was clear that the activity of the antioxidants was much higher after adding alga to the cheese, with scores of $54.85 \%$ for the control sample compared to $68.33 \%$ for the samples with Chlorella vulgaris. The difference in the activity of the antioxidants could be attributed to its composition level in the samples or due to the effect of the cooking temperature as pointed out by Réblová (2012), who indicated that the antioxidant activity decreases with increased cooking temperature. The phenolic acids are not all affected by the cooking temperature between $90-150^{\circ} \mathrm{C}$, while the effect of temperature on metal elements such as selenium will not be the same as the effect on phenolic acids or antioxidant vitamins such as vitamin E. Hence the difference in the antioxidant activity could be either due to the cooking temperature, or to the sample composition and its content of antioxidants and their type.

Table 9. Antioxidant content of processed cheese made using Chlorella vulgaris (4\%)

\begin{tabular}{lc}
\hline \multicolumn{1}{c}{ Treatments } & Antioxidants activity, \% \\
\hline Control & 54.85 \\
Chlorella cheese & 68.33 \\
\hline
\end{tabular}




\section{Improvement of analog processed cheese properties}

This part discusses the improvement of the properties of processed cheese with alga to adjust the defects which appeared in the resulting cheese in the first part of the research. The defects were the granular texture, high oiling off and high meltability.

To improve the textural properties, Chlorella vulgaris was studied in the form of slurry for manufacture of analog processed cheese. To improve the oiling off and meltability, S9S and S4 emulsifying salts were tested in manufacture of analog processed cheese as shown in Table 2. Emulsifying salts are of major importance in processed cheese production, as they are used to provide a uniform structure during the melting process. The essential role of emulsifying salts in the manufacture of processed cheese is to supplement the emulsifying capability of cheese proteins. This is accomplished by removing calcium from the protein system, and peptizing, hydrating, swelling, solubilizing and dispersing the protein. In addition, it emulsifies fat to stabilize the emulsion, controls $\mathrm{pH}$ and forms an appropriate structure after cooling (Awad et al., 2002). The research has revealed the following results:
Sensory evaluation. As shown in Table 10, all treatments were acceptable for surface appearance, flavor, spreading quality and oil separation, and the cheese samples made using S4 emulsifying salt were the best for firmness of body and spreading quality. But with regard to granular texture, treatments made using dried soft powder of alga had low scores in terms of smoothness of texture and breakdown properties.

The granular texture completely disappeared in cheese made using slurry of alga, and this can be inferred based on the degrees of arbitration of smoothness of texture in Table 10. This may be due to using the alga in the form of slurry. Oiling off was absent in all treatments and this explain that emulsifying salts (S4 and S9S) were better than Kasomel emulsifying salt (K-2394).

Chemical analysis. The results in Table 11 show that total solids and fat values were acceptable in all samples. The $\mathrm{pH}$ value of cheese samples made with dried alga were higher than the control, ranging from 6.00 to 6.05 and from 5.77 to 5.83 in cheese with alga and control samples respectively. This may be due to the high value of alga $\mathrm{pH}$. But $\mathrm{pH}$ in cheese sample with slurry alga was lowest (5.68).

Table 10. Sensory evaluation of processed cheese analogue made using different emulsifying salts

\begin{tabular}{|c|c|c|c|c|c|c|c|}
\hline \multirow[t]{2}{*}{ Attribute } & \multicolumn{2}{|c|}{ Control } & \multicolumn{2}{|c|}{$\begin{array}{l}\text { Processed cheese } \\
\text { with dried } \\
\text { Chlorella vulgaris }\end{array}$} & \multirow{2}{*}{$\begin{array}{l}\text { Processed cheese } \\
\text { with slurry } \\
\text { Chlorella vulgaris } \\
\text { S4 }\end{array}$} & \multicolumn{2}{|c|}{ Score limit (1-5) } \\
\hline & S9s & S4 & S9s & $\mathrm{S} 4$ & & & \\
\hline Surface appearance & 5 & 4 & 3 & 3 & 4 & (1) very dull & (5) very shiny \\
\hline Firmness of body & 2 & 3 & 2 & 3 & 3 & (1) very soft & (5) very firm \\
\hline Spreading quality & 4 & 3 & 4 & 3 & 3 & (1) difficult to spread & (5) easy to spread \\
\hline Stickiness & 4 & 3 & 4 & 4 & 3 & (1) not sticky & (5) very sticky \\
\hline Smoothness of texture & 4 & 5 & 2 & 2 & 4 & (1) not smooth & (5) very smooth \\
\hline Breakdown properties & 4 & 4 & 2 & 2 & 3 & (1) does not dissolve & (5) dissolves very well \\
\hline Oil separation & 1 & 1 & 1 & 1 & 1 & (1) absent & (5) very pronounced \\
\hline Flavor & 5 & 5 & 3 & 3 & 4 & (1) very weak & (5) very strong \\
\hline Saltiness & 3 & 3 & 3 & 3 & 3 & (1) not salty & (5) very salty \\
\hline Over all preference & 5 & 4 & 2 & 2 & 4 & (1) dislike very much & (5) like very much \\
\hline
\end{tabular}

Slurry alga cheese made using only S4 emulsifying salt. 
Tohamy, M. M., Ali, M. A., Shaaban, H. A.-G., Mohamad, A. G., Hasanain, A. M. (2018). Production of functional spreadable processed cheese using Chlorella vulgaris. Acta Sci. Pol. Technol. Aliment., 17(4), 347-358. http://dx.doi.org/10.17306/J.AFS.2018.0589

Table 11. Chemical analysis of processed cheese made using Chlorella vulgaris

\begin{tabular}{llccc}
\hline Ingredients & $\begin{array}{c}\text { Emulsi- } \\
\text { fying } \\
\text { salts }\end{array}$ & Control & $\begin{array}{c}\text { Dried } \\
\text { Chlorella } \\
\text { vulgaris } \\
\text { cheese }\end{array}$ & $\begin{array}{c}\text { Slurry } \\
\text { Chlorella } \\
\text { vulgaris } \\
\text { cheese }\end{array}$ \\
\hline Total solids & S9s & 46.88 & 45 & - \\
& S4 & 45.96 & 46.59 & 46.96 \\
& K-2394 & 45.01 & 45.24 & - \\
Fat & S9s & 22.9 & 22.6 & - \\
& S4 & 22.7 & 22.8 & 22.9 \\
& K-2394 & 22.5 & 22.6 & - \\
& S9s & 5.83 & 6.03 & - \\
& S4 & 5.83 & 6.05 & 5.68 \\
& K-2394 & 5.77 & 6 & - \\
\hline
\end{tabular}

Slurry alga cheese made using only S4 emulsifying salt.

Rheological properties. Table 12 shows the rheological properties (oiling off, meltability and penetrometer degree) of analog processed cheese to study the best emulsifying salt. Both S9S and S4 emulsifying salts were better than Kasomel emulsifying salt for studied rheological properties. For oiling off, Kasomel cheese samples demonstrated the highest values. Oiling off rates of cheese samples made using S9S and S4 emulsifying salts were identical to the results of Mohamed et al. (2011). Meltability of chlorella cheese samples were nearest to control samples when using both S9S and S4 emulsifying salts, while the meltability of cheese samples made using Kasomel emulsifying salt was very high. The cheese samples made using Kasomel emulsifying salt had the highest degree of penetrometer reading (150 and $120.5 \mathrm{~mm}$ in control and chlorella cheese respectively) while the cheese samples made with $\mathrm{S} 4$ emulsifying salt were the lowest (75 and $102.5 \mathrm{~mm}$ in control and chlorella cheese respectively).

Based on the previous results, we found that both S9S and S4 can be used for the manufacture of analogue processed cheese made with Chlorella vulgaris and the best emulsifying salt is S4. Cheese samples made with slurry alga had acceptable degrees of oiling
Table 12. Rheological properties of processed cheese made using slurry Chlorella vulgaris

\begin{tabular}{llccc}
\hline $\begin{array}{l}\text { Rheological } \\
\text { properties }\end{array}$ & $\begin{array}{c}\text { Emul- } \\
\text { sifying } \\
\text { salts }\end{array}$ & Control & $\begin{array}{c}\text { Dried Chlo- } \\
\text { rella vulga- } \\
\text { ris cheese }\end{array}$ & $\begin{array}{c}\text { Slurry Chlo- } \\
\text { rella vulga- } \\
\text { ris cheese }\end{array}$ \\
\hline $\begin{array}{l}\text { Oiling off } \\
\%\end{array}$ & S9s & 12 & 28 & - \\
& S4 & 10 & 28 & 11 \\
$\begin{array}{l}\text { Melting } \\
\text { index } \\
\text { mm }\end{array}$ & $\mathrm{K} 9 \mathrm{~s}$ & 92 & 43 & - \\
& $\mathrm{S} 4$ & 95 & 104 & - \\
$\begin{array}{l}\text { Penetrometer } \\
\text { reading } \\
\text { mm }\end{array}$ & $\mathrm{S} 9 \mathrm{~s}$ & 102.67 & 112 & - \\
& $\mathrm{S} 4$ & 75 & 102.5 & 77 \\
\hline & $\mathrm{K}$ & 150 & 120.5 & - \\
\hline
\end{tabular}

Slurry alga cheese made using only S4 emulsifying salt.

off, melting index and penetrometer reading. This explains that using slurry of Chlorella vulgaris in processed cheese manufacture is suitable.

\section{CONCLUSION}

This study has highlighted the nutritional value of Chlorella vulgaris, due to its rich content of fiber, metal elements, vitamins and antioxidants, which are nutritional compounds that support health and protect humans from many diseases. From the results of the study, we recommend supporting the manufacture of the processed cheese with the addition of $2 \%$ of the Chlorella vulgaris alga in soft powder form and $4 \%$ of the Chlorella vulgaris alga in slurry form at the end of processing, so that the cooking temperature does not damage the useful nutrients found in this alga, hence improving the processed cheese product for fostering better health and supporting the nutritional value. Research is also recommended using S4 emulsifying salt for the manufacture of analog processed cheese with slurry of Chlorella vulgaris. 


\section{REFERENCES}

Abd El-Razik, M. M., Mohamed, A. G. (2013). Utilization of acid casein curd enriched with Chlorella vulgaris biomass as substitute of egg in mayonnaise production. World App. Sci. J., 26(7), 917-925. http://dx.doi. org/10.5829/idosi.wasj.2013.26.07.13523

AOAC (2006). Official methods of analysis, $18^{\text {th }}$. Washington, D.C., USA: Association of the Official Analytical Chemists.

Awad, R. A., Abdel-Hamid, L. B., El-Shabrawy, S. A., Singh, R. K. (2002). Texture and microstructure of block type processed cheese with formulated emulsifying salt mixtures. LWT - Food Sci. Technol., 35(1), 54-61. https://doi.org/doi: 10.1006/fstl.2001.0828

Bachmann, H. (2001). Cheese analogues - a review. Int. Dairy J., 11, 505-515. https://doi.org/10.1016/ S0958-6946(01)00073-5

Becker, W. (2007). Microalgae in human and animal nutrition. In: A. Richmond (Ed.), Handbook of microalgae culture: biotechnology and applied phycology (pp. 312-351). Blackwell Publ. https://doi. org/10.1002/9780470995280.ch18

Beheshtipour, H., Mortazavian, A. M., Mohammadi, R., Sohrabvandi, S., Khosravi-Darani, K. (2013). Supplementation of Spirulina platensis and Chlorella vulgaris algae into probiotic fermented milks. Compr. Rev. Food Sci. Food Safety, 12(2), 144-154. https://doi. org/10.1111/1541-4337.12004

Bimola Devi, Ch., Nandakishore, Th., Sangeeta, N., Gomi Basar, Omita Devi, N., Sungdirenla Jamir, Amuba Singh, M. (2014). Zinc in human health. IOSR J. Dent. Med. Sci., 13(7), 18-23. https://doi.org/10.9790/0853-13721823

Blas-Valdivia, V., Ortiz-Butrón, R., Pineda-Reynoso, M., Hernández-Garcia, A., Cano-Europa, E. (2011). Chlorella vulgaris administration prevents $\mathrm{HgCl}_{2}$-caused oxidative stress and cellular damage in the kidney. J. Appl. Phycol., 23(1), 53-58. https://doi.org/10.1007/ s10811-010-9534-6

Bourne, M. C. (2002). Food texture and viscosity. Elsevier Sci.

Bradley, R. L., Arnold, E., Barbano, D. M., Semerad, R. G., Smith, D. E., Vines, B. K. (1992). Chemical and physical methods. In: R. T. Marshall (Ed.), Standard methods for the examination of dairy products (pp. 433-531). Washington, DC: American Public Health Association.

Brandt, M. A., Skinner, E. B., Coleman, J. A. (1963).Texture profile method. J. Food Sci., 28, 404-409. https://doi. org/10.1111/j.1365-2621.1963.tb00218.x
Caul, J. F. (1957). The profile method of flavor analysis. Adv. Food Res., 7, 1-40. https://doi.org/10.1016/ S0065-2628(08)60245-1

De Leenheer, A. P., Lambert, W. (Eds., 2000). Modern chromatographic analysis of vitamins: Revised and expanded. In: A. P. de Leenheer, W. E. Lambert, J. F. van Bocxlaer (vol. 84). Marcel Dekker: New York. https:// doi.org/10.1021/ja004786c

El-Sayed, A. B. (2011). Photo-bioreactor for algae production and carbon dioxide consumer. Egyptian patent, under reviewing, 1283/2011.

El-Sayed, A. B., Abdalla, F. E., Abdel-Maguid, A. A. (2001). Use of some commercial fertilizer compounds for Scenedesmus cultivation. Egypt. J. Phycol., 2, 9-16.

Faten, L. S., Jihan, M. K., Hala, M. B., Abd-Rabou, N. S., Nawal, S. A. (2014). Production of functional spreadable processed cheese analogue supplemented with chickpea. Int. J. Dairy Sci., 9(1), 1-14. https://doi.org/10.3923/ ijds.2014.1.14

Fox, P. F., Guinee, T. P., Cogan, T. M., McSweeney, P. L. (2017). Processed cheese and substitute/imitation cheese products. In: Fundamentals of cheese science (pp. 589-627). Springer US. https://doi.org/10.1007/ 978-1-4899-7681-9_17

Gouveia, L., Batista, A. P., Raymundo, A., Bandarra, N. M. (2008). Spirulina maxima and Diacronema vlkianum microalgae in vegetable gelled desserts. Nutr. Food Sci., 38(5), 492-501. https://doi.org/10.1108/ 00346650810907010

Gröber, U., Schmidt, J., Kisters, K. (2015). Magnesium in prevention and therapy. Nutrients, 7(9), 8199-8226. https://doi.org/10.3390/nu7095388

Guinee, T. P., Carić, M., Kalab, M. (2004). Pasteurized processed cheese and substitute/imitation cheese products. Cheese Chem. Physic. Microbiol., 2, 349-394. https:// doi.org/10.1016/S1874-558X(04)80052-6

Gyenis, B., Szigeti, J. F., Molnár, N., Varga, L. (2005). Use of dried microalgal biomasses to stimulate acid production and growth of Lactobacillus plantarum and Enterococcus faecium in milk. Acta Agr. Kaposvár., 9(2), 53-59.

Hassan, Z. M. R., Hammad, Y., Hassanin, A. M., Salama, H. (2007). Utilization of soy bean flour and flaxseed flake in the manufacture of processed cheese spread. In: Proceeding of the 10th Egyptian Conference for Dairy Science and Technology (pp. 463-479). November 19-21. The International Agriculture Center, Cairo, Egypt.

Hatano, T., Kagawa, H., Yasuhara, T., Okuda, T. (1988). Two new flavonoids and other constituents in licorice root: their relative astringency and radical scavenging 
Tohamy, M. M., Ali, M. A., Shaaban, H. A.-G., Mohamad, A. G., Hasanain, A. M. (2018). Production of functional spreadable processed cheese using Chlorella vulgaris. Acta Sci. Pol. Technol. Aliment., 17(4), 347-358. http://dx.doi.org/10.17306/J.AFS.2018.0589

effects. Chem. Pharm. Bull., 36(6), 2090-2097. https:// doi.org/10.1248/cpb.36.2090

Jackson, A. (2010). Iron and health. London: TSO (The Stationery Office). Available from: www.tsoshop.co.uk.

Kapoor, R., Metzger, L. E. (2008). Process cheese: Scientific and technological aspects - A review. Compr. Rev. Food Sci. Food Safet., 7(2), 194-214. https://doi. org/10.1111/j.1541-4337.2008.00040.x

Kreitlow, S., Mundtand, S., Lindequist, U. (1999). Cyanobacteria - a potential source of new biologically active substances. J. Biotechnol., 70(1), 61-63. https://doi. org/10.1016/S0168-1656(99)00058-9

Lanham-New, S., Lambert, H. (2012). Potassium. Am. Soc. Nutr., 3, 820-821.https://doi.org/10.3945/an.112.003012

Larmond, E. (1977). Laboratory methods for sensory evaluation of foods. Publ. no. 1637. Ottawa, USA: Research Branch, Canada Depart. Agric.

Ling, E. F. (Ed., 1963). A text book of dairy chemistry. Vol. 2. Practical (3rd ed., pp. 58-65). London: Chapman and Hall.

Matsukawa, R., Wada, Y., Tan, N., Sakai, N., Chiharaand, M., Karub, I. (1998). Antioxidant activity of $\mathrm{CO}_{2}$ fixing microalgae. Stud. Surface Sci. Catal., 114, 641-644.

Merchant, R. E., Andre, C. A. (2001). A review of recent clinical trials of the nutritional supplement Chlorella pyrenoidosa in the treatment of fibromyalgia, hypertension, and ulcerative colitis. Altern. Therap. Health Medic., 7(3), 79-91.

Meyer, A. (1973). Processed cheese manufacture. London: Food Trade Press.

Mohamed, A. G., Abo-El-Khair, B. E., Samah Shalaby, M. (2013). Quality of novel healthy processed cheese analogue enhanced with marine microalgae Chlorella vulgaris biomass. World App. Sci. J., 23(7), 914-925. https://doi.org/10.5829/idosi.wasj.2013.23.07.13122

Mohamed, A. G., Hayam Abbas, M., Hala Bayoumi, M., Jihan Kassem, M., Ali Enab, K. (2011). Processed cheese spreads fortified with oat. J. Am. Sci., 7(7).

Nayra Mehanna, Sh., Fatma Hassan, A. M., El-Messery, T. M., Mohamed, A. G. (2017). Production of functional processed cheese by using tomato juice. Int. J. Dairy Sci., 12(2), 155-160. https://doi.org/10.3923/ijds.2017. 155.160

Olson, N. F., Price, W. V.(1958). Amelting test for pasteurized processed cheese spread. J. Dairy Sci., 41(7), $999-1000$. https://doi.org/10.3168/jds.S0022-0302(58)91038-5

Radhakrishnan, S., Bhavan, P. S., Seenivasan, C., Muralisankar, T. (2017). Nutritional profile of spirulina platensis, Chlorella vulgaris and azollapinnata to novel protein source for aquaculture feed formulation. Austin. J. Aquac. Mar. Biol., 2(1), 1005.

Rayman, M. P. (2000). The importance of selenium to human health. The Lancet, 356(9225), 233-241. https:// doi.org/10.1016/S0140-6736(00)02490-9

Réblová, Z. (2012). Effect of temperature on the antioxidant activity of phenolic acids. Czech J. Food Sci., 30(2), 171-177. https://doi.org/10.17221/57/2011-CJFS

Savello, P. A., Ernstromand, C. A., Kalab, M. (1989). Microstructure and meltability of model process cheese made with rennet and acid casein. J. Dairy Sci., 72(1), 1-11. https://doi.org/10.3168/jds.S0022-0302(89)79073-1

Shalaby, S. M., Yasin, N. M. N. (2013). Quality characteristics of croissant stuffed with imitation processed cheese containing microalgae Chlorella vulgaris biomass. World J. Dairy Food Sci., 8(1), 58-66. https://doi. org/10.5829/idosi.wjdfs.2013.8.1.1118

Shamsia, S., Yacoub, S., Zienaand, H., Safwat, N. (2011). Chemical, microbiological, rheological and organoleptic properties of processed cheese blocks made by using mixture of soybean lecithin and commercial emulsifying salt. J. Agric. Env. Sci. Dam. Univ. Egy., 10(1).

Solowiej, B. (2007). Effect of $\mathrm{pH}$ on rheological properties and meltability of processed cheese analogs with whey products. Polish J. Food Nutr. Sci., 57(3), 125-128.

Surh, Y. J. (2003). Cancer chemoprevention with dietary phytochemicals. Nat. Rev. Canc., 3(10), 768-780. https://doi.org/10.1038/nrc1189

Suhila Saad, A., Laila EL-Mahdi, D., Awad, R. A., Hassan, Z. M. R. (2016). Impact of different food protein sources in processed cheese sauces manufacture. Int. J. Dairy Sci., 11, 52-60. https://doi.org/10.3923/ijds.2016.52.60

Szczesniak, A. S., Brandt, M. A., Friedman, H. H. (1963). Development of standard rating scales for mechanical parameters of texture and correlation between the objective and the sensory methods of texture evaluation. J. Food Sci., 28(4), 397-403. https://doi. org/10.1111/j.1365-2621.1963.tb00217.x

Thomas, M. A. (1973). The use of a hard milk fat fraction in processed cheese. Austr. J. Dairy Technol., 28(2), 77-80.

Tokuşoglu, Ö., Üunal, M. K. (2003). Biomass nutrient profiles of three microalgae: Spirulina platensis, Chlorella vulgaris, and Isochrisisgalbana. J. Food Sci., 68(4), 1144-1148. https://doi.org/10.1111/j.1365-2621.2003. tb09615.x

Tramper, J., Battershill, S., Brandenburg, W., Burgess, G., Hill, R., Luiten, E., ..., Wijffels, R. (2003). What to do in marine biotechnology? Biomol. Eng., 20(4-6), 467471. https://doi.org/10.1016/S1389-0344(03)00077-7 